\title{
The Epic and Philosophy of Beauty in Plato and Aurelius Augustinus (Augustine of Hippo)
}

\section{Monica Adriana Ionescu \\ University of Bucharest}

This paper is about myths, epic, and the philosophy of beauty from a comparative point of view.

Beginning from Plato's myths, as they are represented, more precisely within the dialogues Phaedrus and Symposium, in this paper I shall analyze the concept of beauty, as it is configured within the vast Augustinian work, since his work $D e$ pulchro et apto has been lost. I shall predominantly refer to the works De ordine, De quantitate animae, De musica, Confessiones, De civitate dei. Also, I have to mention that my objective is not an exhaustive approach to this topic.

Plato's concept of beauty takes the shape of myth. Plato revives myth not only as an expression of a fantasy, but, rather, as an expression of what we could refer to as faith. Myth is seen as the most authentic expression of Platonic metaphysics. The myth seeks clarification in the logos, while the logos looks for completion in the myth. The Platonic myth is a probable, 


\section{The Epic and Philosophy of Beauty}

possible narrative; it is an image-thinking (thought-provoking). Plato understands myth as any narrative statement of philosophical topics that is not made in pure dialectical form: "Speaking through myths means an expression through images that stays true as long as we are thinking not only in concepts, but also in images" (Reale: 62).

In Plato's The Symposium, there is the myth of the Birth of Eros, among other myths. It is highlighted in Socrates' discourse. Socrates tells what he found out from Diotima, the woman of Mantinea. Eros was conceived on Aphrodite's birthday. He is the son of Poros (wealth) and Penia (poverty, shortage). Since by his nature itself, he is in love with everything that is beautiful, and since Aphrodite is beautiful, he becomes her committed companion and attendant. Eros is a daemon, neither immortal nor mortal, being halfway between knowledge and ignorance. Since wisdom is one of the most beautiful things, and Eros represents the love for everything that is beautiful, he, therefore, aspires to wisdom. Eros is thus a philosopher, standing alongside those who know (we refer to absolute knowledge) and those who are ignorant of everything.

Love means procreation in the name of beauty, in body and spirit. There are four stages of complete initiation into 


\section{Monica Adriana Ionescu}

beauty: physical beauty, moral beauty, beauty of knowledge (and sciences) and beauty itself, the absolute one. As for physical beauty, the one who aims at beauty itself must love a single body, then all of them. Afterwards, one will treasure the beauty of the souls, then the beauty of people's trades and of the laws and then of the sciences, and from the different sciences one will reach a single one: the science of beauty or the beauty itself.

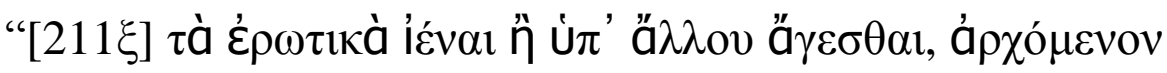

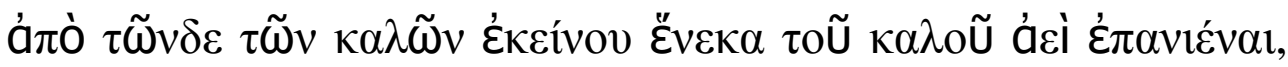

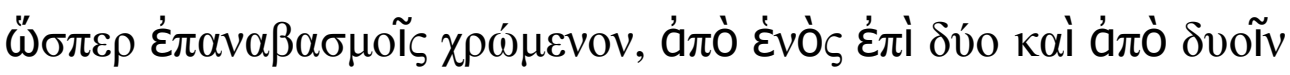

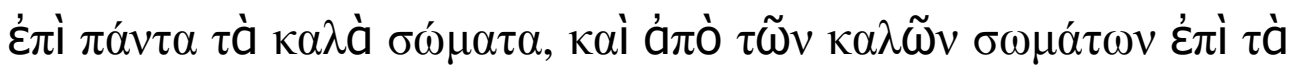

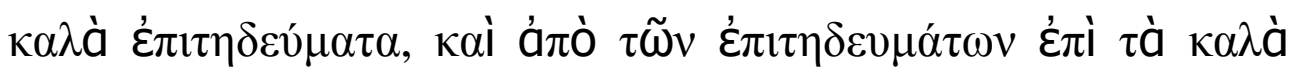

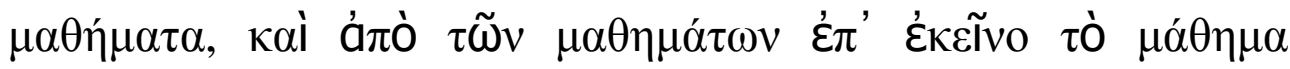

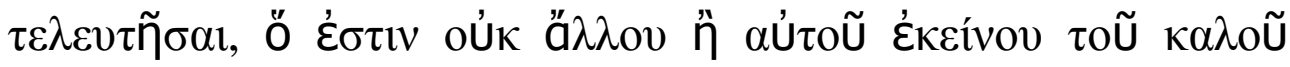

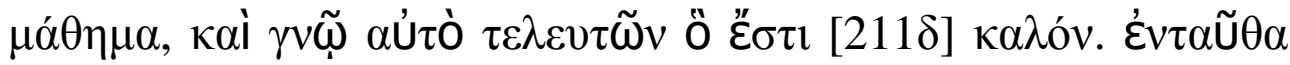

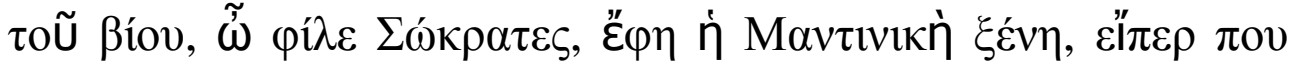

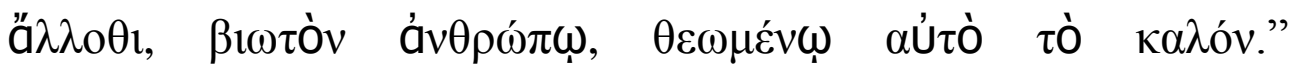
(Symposium, 211, c-d)

Love is a means of knowledge and the one who reaches the end of love initiations will suddenly glimpse a miraculous beauty: a never ending beauty that has no beginning and no end; 


\section{The Epic and Philosophy of Beauty}

that has no ups and downs. This beauty has the attributes of the Parmenidean being.

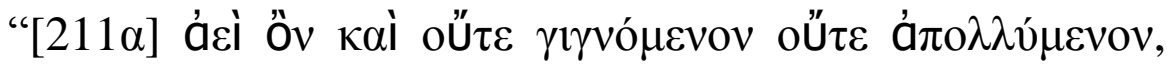

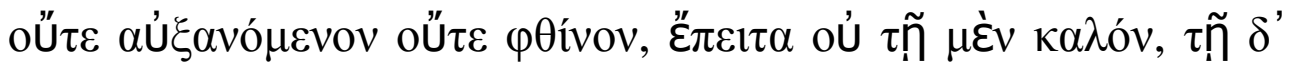

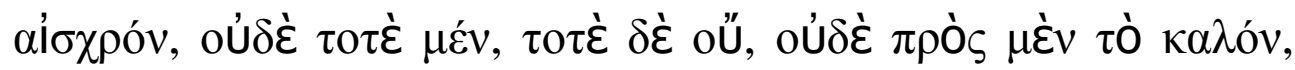

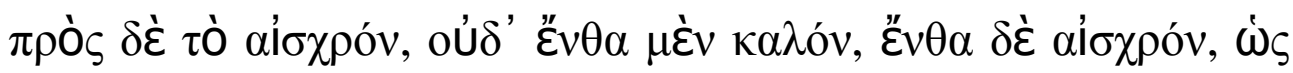

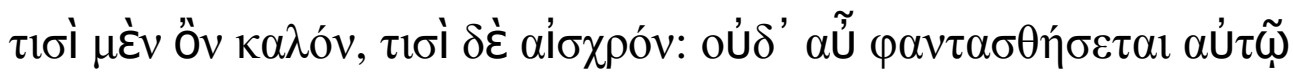

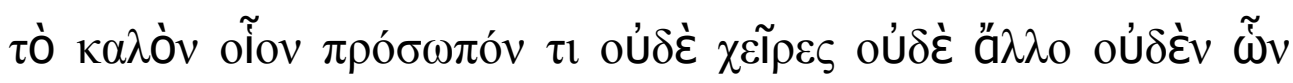

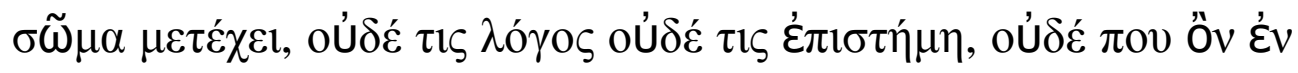

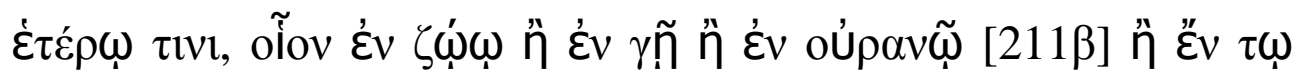

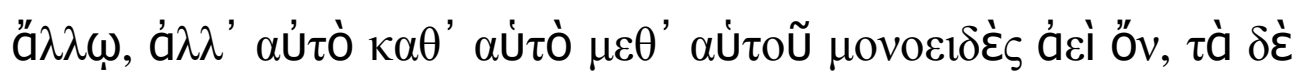

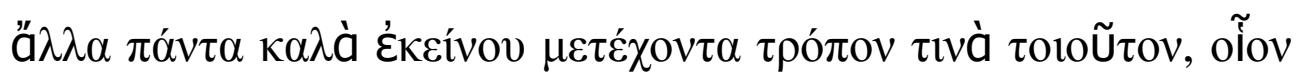

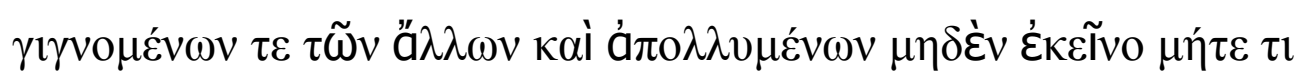

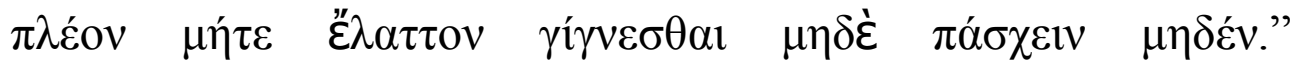
(Symposium, 211, a-b)

In the dialogue Phaedrus, beauty itself is again evoked. Before they incarnate in the human beings, the souls have contemplated this beauty in itself, when it can be viewed in all its splendor. At that time, some engaged in a blissful choir, accompanying Zeus, others followed other gods and all of them contemplated the divine sight. They felt initiated in one of those 


\section{Monica Adriana Ionescu}

mysteries that, one can say with good reason, delivers the purest of joys.

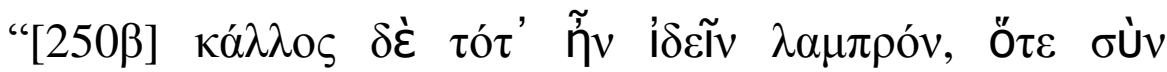

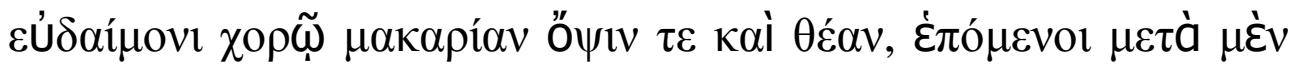

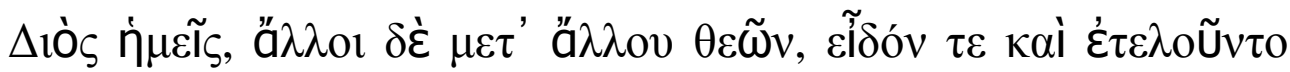

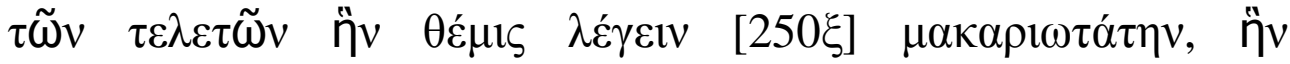

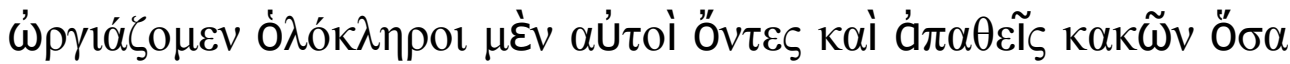

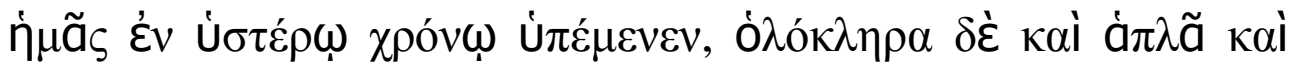

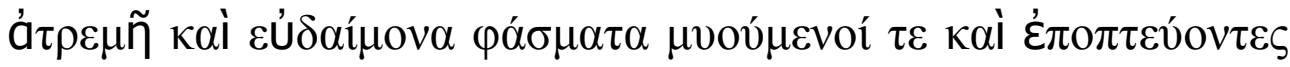

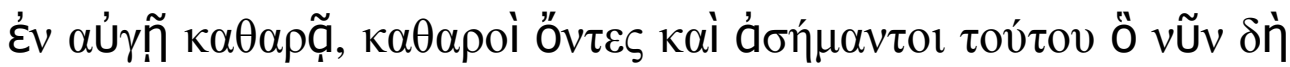

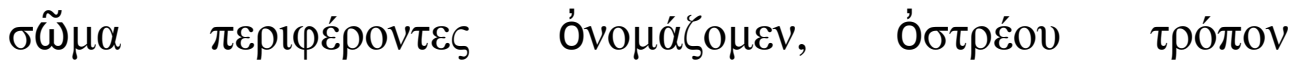

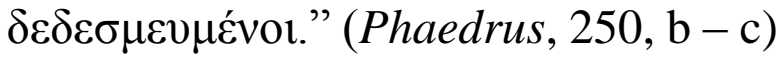

The soul that missed the truth will never be able to enjoy human embodiment. Everything that is spiritual is immortal. The souls that call themselves immortal, when reaching the top, cut through the canopy, seat on their backs and unmoved, let themselves carried away by the wheel of the sky, watching everything that lies beyond it. This place is over the skies and it is intended for the Being itself. The beauty lights up the Being, and the beauty itself is that who attracts the most and who pushes 


\section{The Epic and Philosophy of Beauty}

the man at the same time, making him cross over Beauty beyond itself, towards the Being itself.

In Augustine's perception of sensitive beauty (that can be perceived through the senses) its ultimate feature is unity. "Cui superfunditur aquarum natura, nitens et ipsa ad unitatem, speciosior et perlucidior propter maiorem similitudinem partium, et custodiens locum ordinis et salutis suae." (De musica, VI, 17)

There are a number of basic aesthetical qualities by means of which Augustine explains sensitive beauty, but the aesthetical value conferred by each of them is reducible to a sole quality. In other words, unity is a basic aesthetical quality.

"hoc dicunt etiam quaeque pulchra corpora, quia longe multo pulchrius est corpus quod ex membris pulchris omnibus constat quam ipsa membra singula quorum ordinatissimo conventu completur universum, quamvis et illa etiam singillatim pulchra sunt." (Confessiones, XIII, 28, 43)

There may also be others, such as number, form, similarity, diversity, equality, rhythm or measure, proportion or harmony or symmetry, order, totality, antithesis or contrast. Above them all, there stands unity as a basic aesthetical quality in Augustine's system. 


\section{Monica Adriana Ionescu}

Unity is the cause of beauty. "Deus enim creator est omnium, qui ubi et quando creari quid oporteat uel oportuerit, ipse nouit, sciens uniuersitatis pulchritudinem quarum partium

uel similitudine uel diuersitate contexat." ( De civitate dei, XVI, 8)

Augustine is the one who gives the canonical formulation of the old noble Pythagorean notion of beauty for the Middle Ages: "Only the beautiful is liked; in beautiful - forms; in forms proportions; in proportions - the numbers."

"Hinc est profecta in oculorum opes et terram coelumque collustrans, sensit nihil aliud quam pulchritudinem sibi placere, et in pulchritudine figuras, in figuris dimensiones, in dimensionibus numeros; quaesivitque ipsa secum utrum ibi talis linea talisque rotunditas vel quaelibet alia forma et figura esset, qualem intellegentia contineret." (De ordine, liber II, 15, 42)

Bunum pulchritudinis is part of the category of the relative good that comes from God, but without being the same as the supreme good. The explanation is that the human being is ontologically superior to the animal world and, therefore, his/her beauty is superior to that of the animal, whose beauty will be called by opposition ugliness, deformitas, etymologically from deviation. Augustine is the inheritor of an ancient concept 


\section{The Epic and Philosophy of Beauty}

according to which the more the being is caught in the whirl of matter, the more it lacks beauty, and true beauty reveals itself brighter and brighter as we climb the stairs of the being. Thus, when compared to the superior beauty of man's form, the beauty of the monkey is called ugliness.

Augustine also recognizes intelligible beauty or the beauty that is accessible only to the mind. Intelligible beauty is nonphysical. The examples belonging to this category are the following: philosophy, wisdom, virtue and God.

In Confesions, God's beauty is glorified in terms of ambivalence, oxymoronically. The oxymoronic expression insatiabilis satietas reminds of the endless love for God's beauty. But the purpose of love is never ascension to God through the negation of this world. God or true beauty is worshiped through vertical love. "sero te amavi, pulchritudo tam antiqua et tam nova, sero te amavi!" (Confessiones, liber X, 27, 38)

In conclusion, I will evoke Augustine with the actions of the soul, related to his seven steps (of the soul), as appearing in the work De quantitate animae.

"Agit enim hoc multo quam caetera attentior. Ascendentibus igitur sursum versus, primus actus, docendi causa, dicatur animatio; secundus, sensus; tertius, ars; quartus, virtus; 


\section{Monica Adriana Ionescu}

quintus, tranquillitas; sextus, ingressio; septimus, contemplatio. Possunt et hoc modo appellari: de corpore; per corpus; circa corpus; ad seipsam; in seipsa; ad Deum; apud Deum. Possunt et sic: pulchre de alio; pulchre per aliud; pulchre circa aliud; pulchre ad pulchrum; pulchre in pulchro; pulchre ad pulchritudinem; pulchre apud pulchritudinem." (De quantitate animae, 35)

\section{BIBLIOGRAPHY}

Augustinus, Opera Omnia, Bucharest: Dacia Publishing House, 2002

Augustinus, http://www.thelatinlibrary.com/

Gadamer, Hans-Georg, Vérité et Méthode, Paris: Editions du Seuil, 1976

Gilson, Étienne, Filozofia în Evul Mediu, Bucharest: Humanitas Publishing House, 1995

Plato, Opere, Bucharest: Ştiinţifică Publishing House, 1976 1993

Reale, Giovanni, Istoria Filosofiei Antice, vol. 3, Galaxia: Gutenberg Publishing House, 2009

Schleiermacher, F.D.E., Hermeneutica, Bucharest: Polirom Publishing House, 2001 